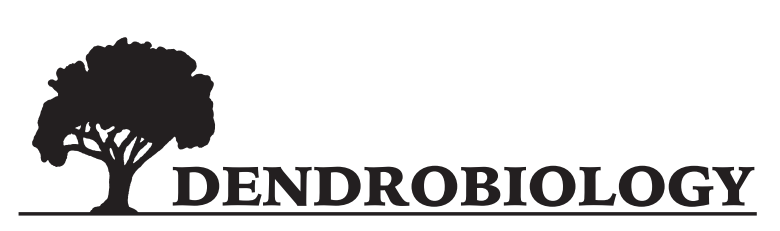

2022, vol. 87, 13-26

https://doi.org/10.12657/denbio.087.002

\author{
Pelin Acar, Funda Ö. Değirmenci, Hayri Duman, Zeki Kaya*
}

\title{
Molecular phylogenetic analysis resolving the taxonomic discrepancies among Salix L. species naturally found in Turkey
}

Received: 26 August 2021; Accepted: 31 December 2021

\begin{abstract}
Detailed phylogenetic relationships and molecular dating are still quite rare for the complex and diverse genus Salix L. Here we focus on the taxonomic status and phylogeny of twenty-six Salix taxa naturally found in Turkey using the chloroplast DNA regions ( $\operatorname{trn} T-F$, matK, and $r b c L$ ) to unravel the relationship among them. The status of Salix species was also checked in the phylogenetic tree constructed with the data from Internal Transcribed Spacer (ITS) region of nuclear gene, including 158 accessions from the GenBank and 126 newly generated sequences of 26 Salix taxa (24 species) naturally found in Turkey. The phylogenetic analysis of the sequence data from both the chloroplast (cpDNA) and nuclear (nrDNA) DNA regions enabled a reliable classification of the genus at the subgeneric level (Salix and Vetrix) with high posterior probability/ bootstrap values as $1 / 100$. The study provides important information on the Salix phylogenetic placements and diverging times of S. pentandroides, S.apoda, S. armenorossica, S. pseudomedemii, S. pedicellata subsp. pedicellata, S. pseudodepressa, S. amplexicaulis, two subspecies of S.triandra, and two endemic species of Turkey (S. purpurea subsp. leucodermis and S. rizeensis) for the first time. Taxonomically, S. amplexicaulis and S. rizeensis previously classified under the subgenus Vetrix were clustered phylogenetically under the subgenus Salix. Subgenera Salix species appears to be diverged from the subg. Vetrix in Eocene (ca. 45.1 Mya) while the estimated divergence times of subg. Salix and subg. Vetrix dated back to 23.1 and 21.65 Mya, respectively. However, divergence times among species within Salix and Vetrix subgenera of Turkey seem to be around the Pliocene period. Molecular phylogenetic relationship between Salix species native to Turkey and Salix species from the world were mainly associated with taxonomic hierarchy, rather than geographic proximity.
\end{abstract}

Keywords: Salix L., cpDNA, nrDNA, molecular phylogeny and dating, Turkey

Addresses: P. Acar, Funda Ö. Değirmenci, Z. Kaya, Department of Biological Sciences, Middle East Technical University, 06800 Ankara, Turkey; ZK (i) https://orcid.org/0000-0001-9381-9688, e-mail: kayaz@metu.edu.tr

P. Acar, Present Address: National Botanical Garden of Turkey, Ministry of Agriculture and Forestry, 06800 Ankara, Turkey; (i) https://orcid.org/0000-0001-8383-9431, e-mail: pelinkeske@gmail.com F. Ö. Değirmenci, Faculty of Agriculture, Department of Field Crops, Ahi Evran University, 40100 Kırşehir, Turkey; (i) https://orcid.org/0000-0002-8875-0273, e-mail: funda07@gmail.com

H. Duman, Department of Biology, Gazi University, 06560 Ankara, Turkey;

(1) https://orcid.org/0000-0001-6387-8652, e-mail: hduman@gazi.edu.tr

*Corresponding author 


\section{Introduction}

Salix L. (willows) is the largest genus of Salicaceae occurring mainly in the Northern Hemisphere (Argus, 1997). Willows have a variety of uses ranging from modern phytotherapy (Mahdi et al., 2006; Akyürek \& Acar, 2020) to the phytoremediation of anthropogenic factors (Evlard et al., 2014) due to their rapid growth and adaptation to a wide range of environmental stresses (Vermerris, 2008). Furthermore, the rapid growth capability of the trees makes them a promising potential for bioenergy production. Around the world, the number of reported willow species varies from 350 (Skvortsov, 1999) to over 500 species (Fang, 1987; Hardig et al., 2010; Wu et al., 2015). Turkey is a prominent country with respect to the richness of biodiversity including forest trees and shrubs (Kaya \& Raynal, 2001). One of the most significant members of the Anatolian riparian forests is Salicaceae species (Skvortsov, 1999; Degirmenci et al., 2019). The Anatolia (Asian part of Turkey), considered as the land bridge between Europe and Asia, has diverse ecosystems created by variable climatic and geographical conditions as well as the geographical barrier (Anatolian Diagonal) run from the north (Gümüşhane-Bayburt) to southwest (the Taurus Mountains) across Turkey (Ekim \& Güner, 1986). The Anatolian Diagonal involves mountain ranges divide the Irano-Turanian phytogeographic region of Turkey into the east and west (Mutun, 2016) and causes the differentiation of taxa at the species and subspecies level (Bilgin, 2011).

In comparison with Northern Europe, Turkey was not totally covered by ice sheets during the last glacial period (Erinç, 1978). Thus, Turkey acted as the glacial refuges and reservoirs of biodiversity including Salicaceae species. Today, there are 27 willow species naturally found in Turkey (Acar et al., 2020). The richest region of Turkey for Salix species is Northern Anatolia. It is followed by the Eastern and Southeastern Anatolia regions (Arıhan \& Güvenç, 2009). Among 27 Salix species, four species and/or subspecies are endemic to Turkey, namely S.trabzonica A. Skv., S. purpurea subsp. leucodermis L., S. rizeensis A. Güner et J. Zieliński (Terzioğlu et al., 2007), and S. anatolica J. Zieliński and D. Tomaszewski (Güner, 2000; Zieliński \& Tomaszewski, 2007).

The genus Salix is well known as one of the few woody genera with a large number of polyploid taxa. About $40 \%$ of the willow species are polyploid having allopolyploid origin (Wagner et al., 2020), ranging from diploid to octoploid species with the basic chromosome number of 19 (Argus, 1997). This high polyploidy level that resulted in Salix hybrids was reported to be an important mechanism in evolution (Karrenberg et al., 2002). The nature and origin of hybridization in the genus Salix are still unclear due to the lack of studies. Evolutionary forces such as dioecious reproduction, natural formation of hybrids, polyploidy, and introgression seem to generate taxonomical problems in Salix, which are still debated worldwide (Kuzovkina et al., 2008; Hörandl et al., 2012; Wagner et al., 2018) and a consensus has not been realized until now. High morphological variability in willows has been resulted in taxonomic confusion (Dorn, 1976). Argus (2000) treated Chosenia and Toisusu as genera in Salicaceae. However, Skvortsov (1999) categorized them as a subgenus since they have only a few different features. In Skvortsov (1999) system, the genus is divided three subgenera: Salix, Vetrix, and Chamaetia. Ohashi (2001) recognized two additional subgenera (Chosenia and Toisusu) and further grouped the Salix genus into six subgenera. The genus is generally divided into five subgenera: Salix subg. Salix s. str., subg. Longifoliae (Andersson) Argus, subg. Protitae Kimura, subg. Chamaetia (Dumort). Nasarov in Kom., and subg. Vetrix Dumort. (Argus, 2010; Wu et al., 2015; Wagner et al., 2018). Skvortsov (1999) reviewed the Salix species native to Turkey and reported the existence of two subgenera (Salix and Vetrix) and 13 sections. The oldest fossil record of subg. Salix and subg. Vetrix from North America dated back to Eocene (33.9-56 Million years ago/Mya) and Oligocene (23-33.9 Mya), respectively (Wolfe, 1987). European and Russian Salix fossils were recorded in Oligocene (Collinson, 1992).

Traditional methods (morphological identification) of taxonomy are insufficient for identifying the members of the genus Salix. In several studies, molecular phylogenetic methods were used to address the phylogenetic issues of the genus, but these studies did not include the Salix species native to Turkey (Brunsfeld et al., 1991; Leskinen \& Alström-Rapaport, 1999; Azuma et al., 2000; Hardig et al., 2010; Chen et al., 2010; Abdollahzadeh et al., 2011; Wu et al., 2015; Lauren-Moreau et al., 2015; Liu et al., 2016; Wagner et al., 2018; Wagner et al., 2020).

The three non-coding chloroplast DNA (cpDNA) regions trn $T-F$ intergenic spacer, the chloroplast coding gene maturase Kinase (matK), the ribulose-1,5-bisphosphate carboxylase/oxygenase large subunit $(r b c L)$ gene, and the ribosomal internal transcribed spacer (ITS) region of nuclear DNA (nrDNA) are commonly preferred in molecular phylogenetic studies since they provide sufficient data to answer questions in phylogenetic reconstruction and classification (Pirie et al., 2007; Hilu et al., 2003; Savolainen et al., 2000; Alvarez \& Wendel, 2003). A recent study on Salix species naturally found in Turkey (Acar et al., 2020) stressed the importance of multiple sequences from both nuclear and chloroplast genomes are needed to resolve taxonomic discrepancies present in the 
genus and to reveal proper phylogenetic placements of species.

In the current study, we aimed to provide valuable molecular data to fill the gap in Salix molecular phylogeny by extensive sampling of Salix species native to Turkey and studying both sequences of chloroplast genome (trn T-F intergenic spacer, $m a t K, r b c L$ ) and nuclear genome (ITS). Specifically, the objectives were, (i) to shed a new light on the phylogenetic placement of some taxomically problematic Salix species naturally found in Turkey, (ii) to generate and provide DNA sequence data from chloroplast and nuclear genome of those Salix taxa to reveal interspecific phylogenetic relationships and molecular divergence time and (iii) to investigate evolutionary lineages of Salix species in the world by using ITS sequences available from the GenBank. This novel study unravels the phylogenetic position and molecular dating of some Salix taxa sampled across Turkey at first and explored their relation in the world.

\section{Methods}

\section{Plant materials}

The collection of fresh willow leaves is extremely important for high-quality DNA extraction. Therefore, the sampling period was limited to only from Spring to mid-Summer. The collected fresh leaves were preserved in silica gel until the DNA extraction experiments. For each species, at least two samples were taken from different locations of Turkey (Supplementary Table S1). To identify the species accurately, one of the samples of each species was collected with catkins. One hundred and twenty-six individual samples were taken from field collections and herbarium specimens. Detailed information on sample locations was provided in Fig. 1. The species identifications were made mainly according to the Flora of Turkey (Davis, 1965). Other relevant databases such as Turkish Plant Lists-Vascular Plants

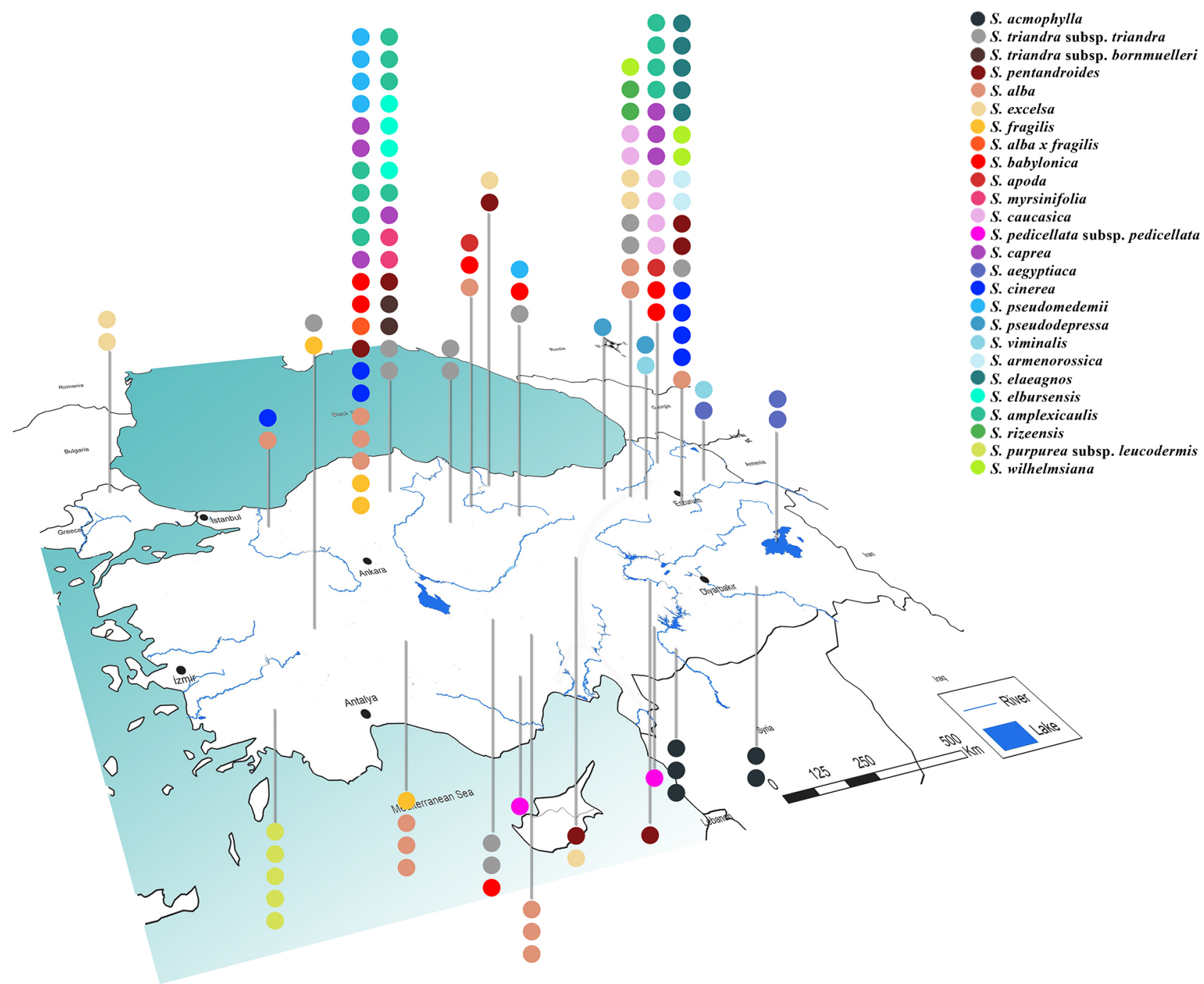

Fig. 1. The locations of each Salix species native to Turkey 
Table.1 Information on accession code, country, subgenera name and the numbers of taxa used in ITS phylogenetic tree

\begin{tabular}{|c|c|c|c|c|c|c|c|c|c|}
\hline & Code & Country & $\begin{array}{l}\text { Subg. } \\
\text { Salix }\end{array}$ & $\begin{array}{l}\text { Subg. } \\
\text { Vetrix }\end{array}$ & $\begin{array}{c}\text { Subg. } \\
\text { Chamaetia }\end{array}$ & $\begin{array}{c}\text { Subg. } \\
\text { Protitea }\end{array}$ & $\begin{array}{c}\text { Subg. } \\
\text { Longifoliae } \\
\end{array}$ & $\begin{array}{c}\text { Subg. } \\
\text { Chosenia }\end{array}$ & Total number of taxa used \\
\hline 1 & TR & Turkey & 7 & 19 & & & & & 26 \\
\hline 2 & IR & Iran & 9 & 10 & & & & & 19 \\
\hline 3 & RU & Russia & 1 & 14 & 12 & & & & 27 \\
\hline 4 & $\mathrm{CH}$ & China & 13 & 6 & 3 & 2 & 1 & & 25 \\
\hline 5 & SW & Sweden & 5 & 3 & 2 & & & & 10 \\
\hline 6 & $\mathrm{CA}$ & Canada & & 3 & & & & & 3 \\
\hline 7 & AM & America & 11 & 39 & 16 & 4 & 2 & 1 & 73 \\
\hline 8 & SZ & Switzerland & & 1 & & & & & 1 \\
\hline 9 & Populus_Outgroup_CH & China & & & & & & & 14 \\
\hline \multicolumn{2}{|c|}{ Total } & & 46 & 95 & 33 & 6 & 3 & 1 & 198 \\
\hline
\end{tabular}

(Türkiye Bitkileri Listesi-Damarlı Bitkiler) (Güner et al., 2012), Turkish Plants Data Service (TUBIVES) checklist (Babaç, 2004) and Willow of Russia and Adjacent Countries (Skvortsov, 1999) were also used for the purpose of species identification and taxonomy. For comparative molecular phylogenetic analysis, the ITS sequences of Salix species taxonomically related to Turkish species from the GenBank database (158 accessions) were retrieved to understand the evolutionary divergence and placement of the Salix species (Table 1). Majority of accession were from America, Russia, and China covering mainly five subgenera (subg. s.str Salix, Vetrix, Chamaetia, Protitea, Longifoliae (Table 1)). Details of the downloaded sequences from GenBank were given in Supplementary Table S1.

\section{DNA extraction, amplification and sequencing}

Nuclear DNA was isolated from leaves using a modified cetyltrimethylammonium bromide (CTAB) protocol (Doyle \& Doyle, 1987). The presence and quality of the DNA were assessed using a spectrophotometer (Biodrop $\mu$ Lite, UK). The DNA isolation procedure was repeated and optimized until a sufficient amount and quality of DNA concentration was obtained to be used in polymerase chain reaction (PCR). The diluted DNAs $(10 \mathrm{ng} / \mu \mathrm{l})$ were stored at $4{ }^{\circ} \mathrm{C}$ for a short period, whereas stock DNA samples were stored at $-80{ }^{\circ} \mathrm{C}$ for a long period. The non-coding trn T-L intergenic spacer, tRNA-Leu- trn $L$ and $\operatorname{trn} L-F$ intergenic spacer (trn T-F), coding maturase Kinase (matK), and coding ribulose-1,5-bisphosphate carboxylase/oxygenase large subunit $(r b c L)$ regions of chloroplast DNA and the ribosomal internal transcribed spacer (ITS) region of nuclear DNA were amplified and sequenced using universal primers (Taberlet et al., 1991; Li et al., 1997; Savolainen et al., 2000; Hsiao et al., 1995) for each of the 126 Salix samples coming from 26 Salix taxa of Turkey. The PCR amplifications were performed in $20 \mu \mathrm{l}$ reaction mixture which included $3 \mu$ PCR Mix (5X HOT FIREPol Blend PCR Mix solution with $15 \mathrm{Mm}$ $\left.\mathrm{MgCl}_{2}\right), 0.5 \mu \mathrm{l}$ each primer pair, $4 \mu \mathrm{l}$ template DNA, and $12 \mu \mathrm{l}$ water in $0.2 \mathrm{ml}$ sterile Eppendorf tubes. The PCRs were performed using a thermocycler (Eppendorf Mastercycler, Canada) based on the optimized cycling parameters as follows: an initial denaturation at $95{ }^{\circ} \mathrm{C}$ for $5 \mathrm{~min}$ followed by denaturation at $94{ }^{\circ} \mathrm{C}$ for $1 \mathrm{~min}$, annealing at $58{ }^{\circ} \mathrm{C}$ for $1 \mathrm{~min}$, extension at $72{ }^{\circ} \mathrm{C}$ for $2 \mathrm{~min}$, and a final extension at $72{ }^{\circ} \mathrm{C}$ for $10 \mathrm{~min}$. Agarose gel concentrations of $1 \%$ and $1.5 \%$ were used to visualize the PCR products. The purification and sequencing procedures were carried out by Genoks Molecular Biotechnology Company (Cinnah, Ankara). The chromatogram data obtained from the sequence analysis were viewed using FinchTV software (Version 1.4.0) developed by the Geopiza Research Team (Patterson et al., 2004-2006). All the DNA sequence base peaks were checked for the accuracy of base calling. The multiple alignments were carried out with the ClustalW software. The sequence assembling and sequence molecular diversity parameters were estimated for all sequence data generated from the chloroplast and nuclear DNA by using the MEGA Software version 6.0 (Tamura et al., 2013).

\section{Phylogenetic analysis}

Phylogenetic trees were constructed based on maximum likelihood (ML) and Bayesian inference (BI) analyses. The MrModel software (Nylander, 2004) was used for testing the best suitable substitution model based on the AIC (Akaike information criterion) values. The data were converted to nexus format using DnaSP software (Librado \& Rozas, 2009) and to eXtensible Markup Language (XML) format using BEAUti software (Drummond \& Rambaut, 2007). The formatted data of cpDNA and nrDNA were analyzed by using the BEAST v 2.5.1 (Bayesian Evolutionary Analysis by Sampling Trees) package program, with the options of GTR $+\mathrm{I}+\mathrm{G}$ substitution, Yule tree prior and random starting 
tree models for each partition with four gamma categories and uniform sampling frequencies. These options were applied by sampling all parameters once every 10,000 generations from 10,000,000 Markov Chain Monte Carlo (MCMC) generations. The poplar DNA sequences of studied cpDNA and nrDNA regions were used as outgroups. The Tracer 1.6 (Rambaut et al., 2014) and TreeAnnotator software (Drummond \& Rambaut, 2003) were used to evaluate convergence and to estimate the maximum clade credibility (MCC) tree using Bayesian posterior probability (limit of 1). The Tracer 1.6 was also applied to examine effective sample sizes (ESS) for estimated parameters. For both chloroplast and nuclear sequence data, ESS values were calculated far beyond 200 for both calibrations resulting in reasonable-looking bell-shape posterior probability density curves. Besides, all phylogenetic trees were constructed in MEGA program to estimate bootstrap support values with 1000 replicates in ML option. The bootstrap values (limit of 100) were added to the phylogenetic trees of BEAST analysis (Fig. 2, Fig. 3). The constructed phylogenetic trees with bootstrap values and posterior probabilities of each branches were visualized in the FigTree version 1.4.3 (Rambaut, 2016). Assuming that DNA sequences evolve at a relatively constant rate over time and among different organisms (Futuyma, 2011), a molecular dating analysis of data from cpDNA is useful to understand Salix lineage diversification in Turkey. The molecular dating analyses was carried out by the use of BEAST program with the strict molecular clock option. The split between Salix and Populus as a root node of Salicaceae was assigned to the earliest Populus fossil record dated as 48 Mya for calibration (Wu et al., 2015).

\section{Results}

\section{Polymorphism}

The total sequenced lengths of the ITS, mat $K$, $r b c L$ and $t r n T-F$ sequences were 598, 1727, 1485 and $1347 \mathrm{bp}$, respectively (Table 2). The polymorphism levels were found to be about the same magnitude in both nrDNA (19/598) and cpDNA (123/4550) sequences. Among the studied cpDNA sequences, the trn T-F (56/1347) region was the most variable one. The most variable part of $\operatorname{trn}$ the $T-F$ was the $\operatorname{trn} L$ intron region. The nucleotide diversity as a measure of overall polymorphism was estimated as 0.017 for the non-coding cpDNA trn T-F sequence. The variable sites were higher at the sequence of 5' region (matK1) compared to the sequences adjacent to the 3' (matK2) ends. The most conserved sites were found in the $r b c L$ region of cpDNA. The highest transition (79.24), transversion substitution (20.76) and transition-transversion bias (R) (3.51) rates were estimated for the ITS region, which was quite diverse and informative. One insertion (indel) polymorphism was in both ITS and matK regions. In general, the ratio of parsimony informative sites to variable sites was higher in nrDNA (14/19) compared to all cpDNA regions (89/123). The nucleotide diversity estimated for both cpDNA and nrDNA sequences was higher in subg. Vetrix compared to subg. Salix.

\section{Phylogenetic Analysis}

The topologies of ITS and chloroplast trees are not totally in coherence, but Salix of Turkey was mostly resolved as monophyletic in cpDNA tree (Fig. 2). The genus in the cpDNA tree was separated as two well-supported subgenera (Salix and Vetrix) along the other smaller clades $(1,2,3,4,5)$. On the

Table. 2 The estimated molecular diversity parameters based on cpDNA and nrDNA sequences of Salix species native to Turkey data

\begin{tabular}{|c|c|c|c|c|c|}
\hline & \multirow{2}{*}{$\begin{array}{c}\text { nrDNA } \\
\text { ITS }\end{array}$} & \multicolumn{4}{|c|}{ cpDNA } \\
\hline & & matK & $r b c \mathrm{~L}$ & $\operatorname{trnT} \mathrm{T}-\mathrm{F}$ & total \\
\hline Number of species & 26 taxa* & 26 taxa $*$ & 26 taxa $*$ & 26 taxa $*$ & 26 taxa $*$ \\
\hline Number of total sequences & $126^{* *}$ & $126^{* *}$ & $126^{* *}$ & $126^{* *}$ & $126^{* *}$ \\
\hline Total length (bp) & 598 & 1727 & 1485 & 1347 & 4550 \\
\hline GC content $(\%)$ & 64.7 & 32.4 & 43.3 & 30.5 & 35.3 \\
\hline Conserved sites & 578 & 1680 & 1462 & 1289 & 4418 \\
\hline Variable sites & 19 & 45 & 22 & 56 & 123 \\
\hline Parsimony informative sites & 14 & 25 & 15 & 49 & 89 \\
\hline Transitional pairs & 79.24 & 58.79 & 56.77 & 50.62 & 57.23 \\
\hline Transversional pairs & 20.76 & 41.21 & 43.23 & 49.38 & 42.77 \\
\hline Transition/Transversion (tr/tv) (R) ratio & 3.51 & 1.24 & 1.29 & 0.86 & 0.97 \\
\hline Number of indels & 1 (insertion) & 1 (insertion) & 0 & 0 & 1 (insertion) \\
\hline Nucleotide diversity & 0.013 & 0.006 & 0.005 & 0.017 & 0.009 \\
\hline
\end{tabular}

${ }^{*}$ S. alba $\times$ fragilis was included in the analysis as a morphologically identified hybrid taxa.

**Used sequences only from Turkey. 


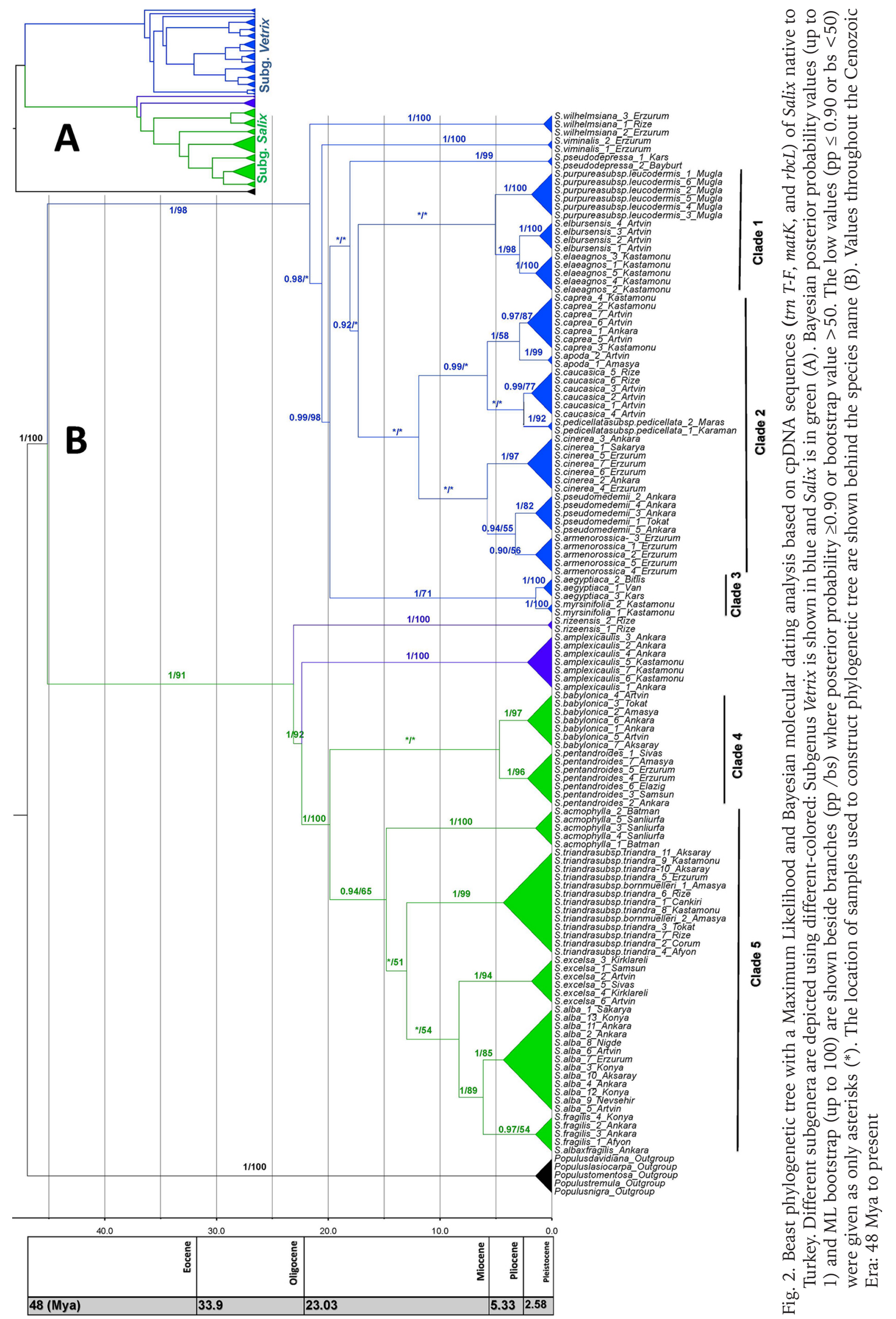



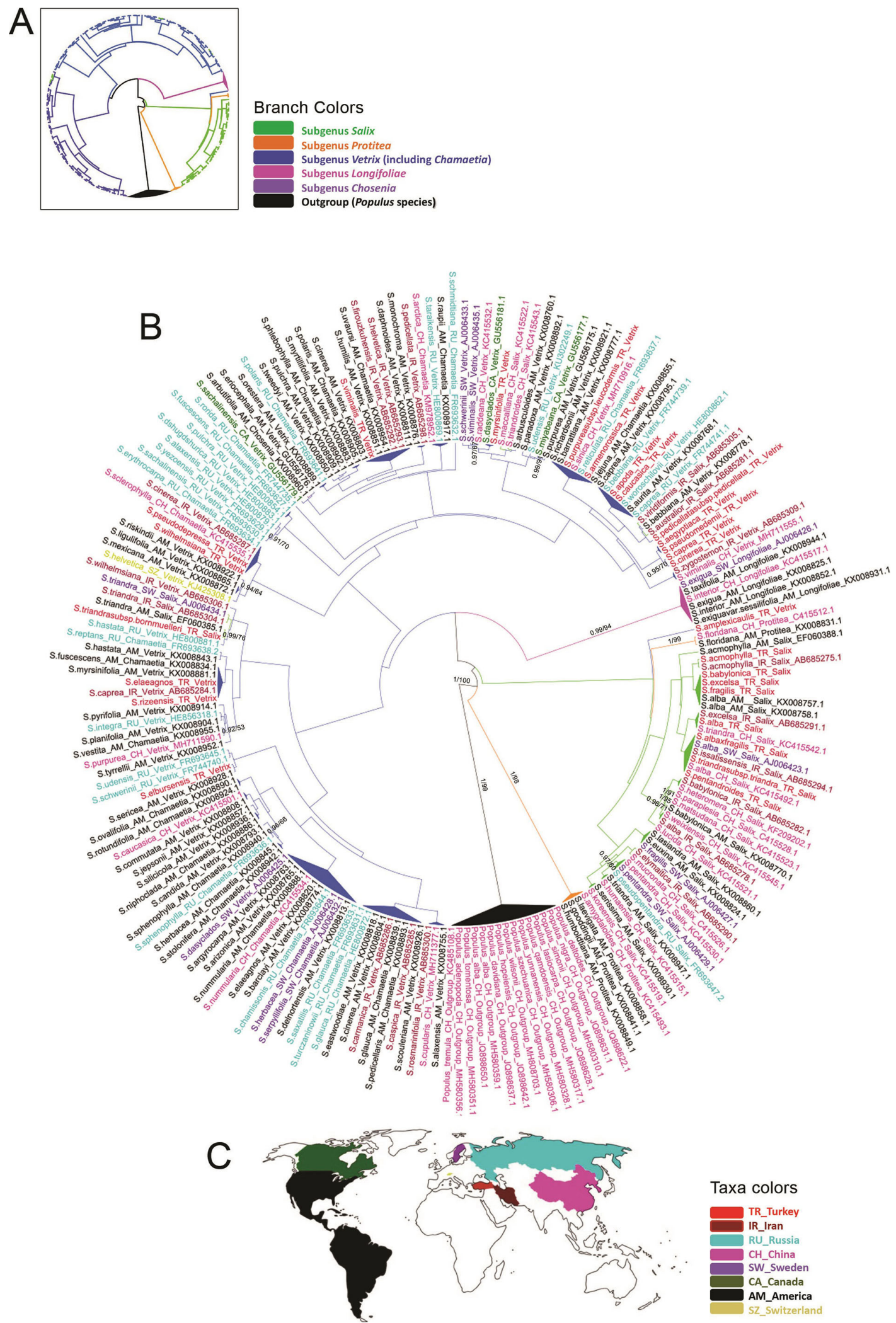

Fig. 3. Beast nrDNA (ITS) phylogenetic tree constructed with world Salix sequences obtained from GenBank. The numbers on branch are posterior probability from the Bayesian inference and the bootstrap values from the maximum parsimony, respectively. The Country abbreviation, Subgenera, GenBank Accession number are indicated behind the species name. (A) Phylogenetic relationships of Salix subgenera. The color in branch and legend represent the subgenera. (B) A detailed phylogeny of Salix species from the world. (C) A map showing the color of country to which species belong in the world. Bayesian posterior probabilities (up to 1) and bootstrap values (up to 100) are shown beside branches ( $\mathrm{pp} / \mathrm{bs}$ ) where posterior probability $\geq 0.90$ or bootstrap value $>50$ 
other hand, ITS tree topology showed five major groups as subg. Salix s. str., Vetrix, Chamaetia, Longifoliae, and Protitea shown in different branch colors (Fig. 3). Most of the subg. Protitea members formed a well-supported monophyletic group with high posterior probability and bootstrap values (1/98) whereas some of them were nested in subg. Salix s. str (orange branch color). A group with blue branch color includes all species of subgenera Chamaetia and Vetrix. Subg. Longifoliae members (pink branch color) were clustered with subgenera Vetrix and Chamaetia. The limited number of individuals (S. arbutifolia) is insufficient to interpret the Chosenia group.

The phylogenetic tree constructed using the data from the chloroplast sequences (trn T-F, matK, and $r b c L$ ) supported two major groups with high posterior probability and bootstrap values as 1/100 (Fig. 2a). The first major group that mostly including species from subg. Vetrix had three clades (Fig. 2b). S. elaeagnos Scop. (all samples from Kastamonu province), S. elbursensis Boiss. (from Artvin), and S. purpurea subsp. leucodermis (from Muğla) were closely related and grouped under Clade 1. The Clade 2 consisted of two subclades. Some members of the section Vetrix such as S. caprea L., S. caucasica Andersson, and S. pedicellata subsp. pedicellata Desf. and one member of the section Hastatae, that is S. apoda Trautv. were submerged under one subclade. The branch values in the representatives of species from different locations were resulted in low posterior probability and bootstrap values compared with the samples of the Clade 1 . The other subclade of the Clade 2 included S. pseudomedemii E. Wolf, S. armenorossica A. Skv. (all from Erzurum), and S. cinerea L. The last clade of subg. Vetrix, the Clade 3 consisted of S. myrsinifolia Salisb. (all from Kastamonu) and S. aegyptiaca L. The sister groups which are distantly located among the members of the subg. Vetrix were S. pseudodepressa A. Skv, S. viminalis L. (all from Erzurum) and $S$. wilhelmsiana Bieb. The second major group of genus Salix (The Clades $4 \& 5$ ) in the cpDNA tree, subg. Salix which was diverged from subg. Vetrix with significant posterior probability and bootstrap values (1/91) included mostly members of the section Salix. The Clade 4 consisted of only S. babylonica L. and S. pentandroides A. Skv. Interestingly, samples of $S$. amplexicaulis Bory and Chaub and S. rizeensis which were reported previously as the members of subg. Vetrix, were located as sister clades with very high posterior probability and bootstrap values among the subg. Salix group $(1 / 100)$. The Clade 5 had two subclades. One of them was with S. alba L., S. excelsa J.F. Gmelin, S. fragilis L., and S. alba $x$ fragilis which had wide distribution range in Turkey. The second subclade of the Clade 5 consisted of S. triandra subsp. triandra L.,
S. triandra subsp. bornmuelleri (Hausskn.) A. Skv., and S. acmophylla Boiss. Samples of S.acmophylla collected from southeastern Turkey. As expected, S. alba $x$ fragilis morphologically identified as hybrid species was very closely associated with $S$. alba (nrDNA) and $S$. fragilis (cpDNA).

The results from the analysis of ITS sequence data revealed the major groups of subg. Salix s. str., Vetrix, Chamaetia, Longifoliae, and Protitea with high posterior probability and bootstrap values $(1 / 100)$ (Fig. 3a). The closest relatives of Salix species of Turkey were determined and shown in Fig. 3. The first major group of the ITS phylogenetic Salix tree was the subgenus Vetrix (including Chamaetia) which involved some clades diverged from other subgenera with high number of taxa (Fig. 3b). One of the Clade of Vetrix (including Chamaetia) was comprised of the closely related species of Turkey (_TR) namely S. pedicellata subsp. pedicellata, S. aegyptiaca, S. pseudomedemii, S. apoda, S. purpurea subsp. leucodermis (endemic to Turkey) and S. armenorossica. S. rizeensis (endemic to Turkey) and S. pseuododepressa were located among American willows. S. caprea and S. cinerea were very closed to each other and grouped under one of the Clades of subgenus Vetrix (0.95/70). Exceptional subg. Salix s. str. members located in major group of subg. Vetrix (including Chamaetia) were S. triandra subsp. bornmuelleri ( TR), S. triandra (_AM, _SW, _IR), S. triandroides (_CH), S. maccaliana (_CH), S. australior (_IR) and S.viridiformis (_IR). The S. triandra subsp. bornmuelleri (_TR) was attached to that clade which involved the other samples of $S$. triandra (_AM, _SW, _IR) with high posterior probability and bootstrap values (0.99/76). Subg. Longifoliae members (S. exigua (_SW, _AM), S. exigua var. sessilifolia (_AM), S. interior (_CH, ifolia $(\mathrm{AM})$ ) formed a distinct subclade in ITS tree $(0.99 / 94)$. The closely related species of subg. Salix s. str. were S. paraplesia (1/91), S. matsudana (1/95), S. weixiensis $(0.96 / 71)$ and $S$. lucida from China. S. acmophylla (_TR, IR, AM), S. babylonica (_TR), S. excelsa (_TR) and S. fragilis (_TR) were grouped with S. floridana_CH and AM under the same Clade of subg. Salix ${ }^{-}$. str.

The molecular dating analyses showed the diversification of subgenera Salix and Vetrix from the Populus species occurred about 46.92 Mya (Fig. 2b). The estimated divergence time of subg. Salix and subg. Vetrix dated back to 23.1 and 21.65 Mya, respectively. The diversification time for two subgenera species in Turkey was found relatively recent (Pliocene). The most recent diverging species seemed to be $S$. viminalis, S. pseudodepressa, S. myrsinifolia, S. apoda, S. pedicellata subsp. pedicellata and S. rizeensis (about 0.36 Mya). 


\section{Discussion}

\section{Phylogenetic implications}

Previous studies have reported that the non-coding regions of chloroplast genome such as trn T-F usually have a high potential for mutation (Taberlet et al., 1991; Bakker et al., 2000; Hamza-Babiker et al., 2009) as found in Salix species of Turkey. The high polymorphism observed in matK is consistent with the findings of Percy et al. (2014) for the North American Salix species. The occurrence of highly variable sites can be explained by the long-aligned sequence of matK including some intron regions of trn $K$. Nevertheless, the conserved 3' end of matK with a high number of informative sites was very useful in resolving taxonomic problems. However, the $r b c L$ region was highly conserved in the studied Salix taxa. This gene had a low resolving power to address the problems of lower taxonomic levels in the genus. Thus, the sequences of uniparentally inherited $\mathrm{cpD}$ NA except for the $r b c L$, have provided sufficient information to comprehend interspecific relations of Salix subgenera (Salix and Vetrix).

The results of the current study from cpDNA data are in accordance with the classification system of Skvortsov (1999) in which the Salix species of Turkey can be classified into two, namely subg. Salix and Vetrix. Similar clade formations have also been reported for the Japanese (Azuma et al., 2000), Chinese (Chen et al., 2010; Zhao et al., 2019) and American Salix species in respected subgenera (Lauren-Moreau et al., 2015). However, the species of subgenera Chamaetia and Vetrix ended up in the same group with moderately high posterior probability and bootstrap values $(0.87 / 76)$ in the ITS phylogenetic tree of the current study. This result including subg. Vetrix species from Turkey is still consistent with previous studies (Azuma et al., 2000; Chen et al., 2010, Wagner et al., 2018), supporting a merge of the two Salix subgenera (Chamaetia and Vetrix) under a single subgenus. Besides, different from other studies (Abdollahzadeh et al., 2011; Lauren-Moreau et al., 2015; Wu et al., 2015), subg. Longifoliae was clustered with subg. Vetrix (including Chamaetia) members, rather than nesting in subg. Salix. Also, the ITS sequences of subg. Protitea (from America and China) resulted in a monophyletic major clade except for two accessions of S. floridana which are roughly related to subgenera. Therefore, unlike other subgenera system, we suggest the division of Salix L. into four subgenera, Salix s. str. and Vetrix (including Chamaetia), Protitea, and Longifoliae for the infrageneric system of Salix in the world.

The members of subg. Salix Section Amygdalinae W.Koch including S. triandra subsp. bornmuelleri ( TR), S. triandra (_AM, _SW, _IR) and S. triandroides
( $\mathrm{CH})$ were located in the subg. Vetrix (including Chamaetia) group of the ITS Salix phylogeny. Since members of this section diverged from the monophyletic nature of the subg. Salix (Chen et al., 2010; Abdollhazadeh et al., 2011), Salix triandra with different ploidy level $(2 \mathrm{x}=2 \mathrm{n}=38)$ is always chosen as an outgroup in Salix phylogeny studies (Wagner et al., 2018; Wagner et al., 2020). Distant position of $S$. triandra was also supported by morphological traits such as life form, bark type, stipule persistence, leaf shape, twig slender, decorticated wood, bud angle and petiole length (Acar et al., 2020). Even if subspecies of Salix triandra were clustered under subg. Salix in our cpDNA tree, the exclusion of Section Amygdalinae W.Koch members from subg. Salix (Wu et al., 2015) was also supported by the ITS data from the current study and morphological data from Acar et al. (2020). As far as both cpDNA and nrDNA based trees are concerned, the most distant species of subg. Vetrix were S. wilhelmsiana and S. pseudodepressa. The distant position of $S$. pseudodepressa can be explained by the phenomena: the rare nature of the species due to its completely isolated natural occurrences in high altitude habitats (Acar \& Usta Baykal, 2020).

Introgressive hybridization and incomplete lineage sorting are generally considered as the sources of phylogenetic contradictory between topology of $\mathrm{cpD}$ $\mathrm{NA}$ and nrDNA trees in willows (Wayne \& Knowles, 2006; Stegemann et al., 2012). It is difficult to identify incomplete lineage sorting or gene flow as a result of interspecific hybridization with the current type of data set. However, hybridization is known to be common among biogeographically close and locally distributed Salix species (Stegemann et al., 2012; Percy et al., 2014). Specifically, subg. Salix species prefers habitats with continental climates such as Central Anatolia (S. fragilis) and Southeastern Turkey (S. acmophylla), whereas the subg. Vetrix species (S. elaeagnos, S. elbursensis, S. apoda, S. myrsinifolia, S. caucasica, and S. rizeensis) are found in and adapted to wet and cool climates of the high latitude and altitude habitats of northern and eastern Turkey (Acar \& Usta Baykal, 2020). Diverse climate and habitats existing in Turkey may facilitate the lateral haplotype transfer (Stegemann et al., 2012) in closely related willow species wherever they share mixed habitats.

\section{Biogeographical implications}

The clear separation of two subgenera of Turkish Salix species may result from different biogeographic barriers such as Anatolian Diagonal and major mountain ranges in southern and northern Turkey. The morphological study on Salix from Turkey confirmed that subg. Salix is a natural group displaying with distinct morphological characteristics such as treelike life forms and lanceolate leaf shapes, while subg. 
Vetrix includes species characterized by evolutionary advanced traits (pubescence on bud scale) (Acar et al., 2020). The subg. Salix section Salix members including S. alba, S. fragilis, S. alba $x$ fragilis, and S. excelsa with many ancestral characters are found as closely related in phylogenetic trees of the current study. Therefore, it is reasonable to assume that the section was dispersed and adopted to the warm-temperature regions of the world (Skvortsov, 1999). The complex relation and extensive polytomy of subg. Vetrix have been observed in the current study as reported by several previous studies (Leskinen \& Alström-Rapaport, 1999; Hardig et al., 2010; Abdollahazadeh et al., 2011; Barkalov \& Kozyrenko, 2014). The observed relationships among subg. Vetrix species could be explained by natural hybridization events since hybridizations are still continued within the geographically close members of the subgenus which are mainly originated in the northern latitudes.

The taxonomically well-defined and geographically distinct Salix species from the world were involved clades in which they are genetically similar in ITS tree. All twenty-six Salix taxa native to Turkey scattered throughout the world Salix accessions (158) and aligned with related subgenera level positions in the analysis. Thus, the close molecular relationships between Salix species of Turkey and Salix species from the world seem to be determined by taxonomical affinities, rather than distinct geographical distribution. Members of subg. Vetrix native to Turkey have close relations with American willows from subg. Vetrix supporting statement that the migration way from Asia to North America caused Salix movement and rapid diversification in subg. Vetrix members (Wu et al., 2015; Özdilek et al., 2012).

Three S. acmophylla_TR, _IR, _AM samples were well allied, but it was the furthest clade of subg. Salix in the ITS Salix phylogeny. The similar placement of S. acmophylla was reported and supported by morphological dataset (Hardig et al., 2010; Acar et al., 2020). Contrary to the ITS tree, the position of S. acmophylla was under subg. Salix in cpDNA tree. The explanation for this may be due to the hybrids occurring between S. alba and S. acmophylla (Abdollahzadeh et al., 2011; Barkalov \& Kozyrenko, 2014). The other scenario for S. acmophylla_TR is that the effect of the Anatolian Diagonal may have caused to speciation due to isolation mechanism created by natural mountain barriers (Bilgin, 2011). The species is likely to be evolved in generally continental climates of eastern Irano-Turanian phytogeographic region of Anatolia.

\section{Molecular dating}

Two main clades of genus Salix in Turkey shared the same biogeography were very similar according to divergence time based on combined cpDNA data
(Oligocene). There are many fossil records from the North America (Wolfe, 1987), Europe and Russia (Collinson, 1992) that estimated Eocene and Oligocene origin of genus Salix. Wu et al. (2015) obtained the crown group age of 23.76 Mya (subg. Vetrix) which is comparable to our findings. The origin and split dating of the Salix subgenera of Turkey went back to Eocene (45.1 Mya), but the occurrence time of most of the species of genus Salix indigenous to Turkey were in Pliocene. Especially, members of subg. Vetrix undergone a recent diversification in high altitude of Anatolia (before $5 \mathrm{Mya}$ ). This dating has been supported by the findings of Kasapligil (1977) who reported the age of Anatolian Salix fossil record dated back to the Pliocene (2.58-5.33Mya). Thus, the last glacial period acting as glacial cover for forest biodiversity (starting from late Pliocene: 2.58 Mya) has an effect on shaping the current composition of Salix species in Turkey (Ledig, 1998).

The new findings on the two (cpDNA data) and five (nrDNA data) subgenera of Salix. L. were summarized in the current study. Although S. amplexicaulis (cpDNA and nrDNA) and S. rizeensis (cpD$\mathrm{NA}$ ) are taxonomically considered the members of subg. Vetrix, the results from the current molecular data suggest that these species are phylogenetically close to subg. Salix. The morphological affinity for S.amplexicaulis and S.rizeensis (both possess glabrous bud scale) supports the recognized phylogenetic positions of both species in subgenus Salix (Acar et al., 2020). The positions of S. rizeensis and S. amplexicaulis in subg. Vetrix instead of in subg. Salix could be due to natural hybridization occurring between different Salix species of Anatolia in a species mixed zone such as Black Sea and Central Anatolia Regions (Supplemantary Table S1). The results of the current study clearly helped to determine the phylogenetic positions of 11 Salix taxa in Turkey (S. pentandroides, S. apoda, S. armenorossica, S. pseudomedemii, S. pedicellata subsp. pedicellata, S. pseudodepressa, S. amplexicaulis, S. purpurea subsp. leucodermis, S. rizeensis, S. triandra subsp. triandra and S.triandra subsp. bornmuelleri) among the world Salix species for the first time. Those new records will also bring new sequence data in Genbank. The findings are important not only for providing new chloroplast and nuclear genome sequence data for future phylogenetic and evolutionary studies, but also for exploring economically valuable species and relatives such as $S$. amplexicaulis with respect to obtaining medicinal products (Alakkarı, 2017; Akyürek \& Acar, 2020).

\section{Conclusion}

The study explored phylogenetic placement of Salix taxa native to Turkey with large number of samples 
based on a combined data sets from cpDNA and nrDNA sequences (4550 bp) for the first time. The constructed phylogenetic tree of the Salix species found in Turkey showed a monophyly and supported well two subgenera (Salix and Vetrix). While two coding cpDNA sequences (matK and $r b c L$ ) were found to be somewhat conserved, the non-coding cpDNA (trn $T-F)$ and nrDNA ITS regions had a high number of variable sites in Salix species. The distant position of S. acmophylla (among species of subgenus Salix), integration of Chamaetia/Vetrix subgenera and removal of Section Amygdalinae W.Koch members from subg. Salix were also strongly supported by our findings. All investigated Salix species have received their taxonomic position of subgenera in ITS Salix phylogenetic tree regardless of geographical origin. The crown age of two subgenera from Turkey was found to be at the Eocene. Subgenus Salix and subg. Vetrix diversification dated back to the Oligocene. The most recently diverged species were found in subg. Vetrix (0.36 Mya). We firmly revealed the phylogenetic positions of 11 Salix taxa with a large amount of data at first time in the world and proposed that phylogenetic positions of S.amplexicaulis and S.rizeensis (endemic to Turkey) species are closer to subg. Salix rather than subg. Vetrix. We believe that the new chloroplast and nuclear genome related DNA sequence data and findings from the current study will greatly contribute to the future Salix phylogenetic and evolution related studies.

\section{Conflicts of interest statement}

The authors declare no potential conflict of interest.

\section{Acknowledgment}

This study has been funded by the Scientific and Technical Research Council of Turkey (TUBITAK) with the project TOVAG 2130154 "Molecular Phylogeny of Turkish Salix L. Species and Genetic Characterization of Two Economically Valuable Willow Species (Salix alba and Salix excelsa) for Tree Breeding Purposes" and supported by Middle East Technical University (METU) with the project BAP-0108-2012-013 "Türkiye Söğüt Türlerinin Moleküler Filogenetiği". We are grateful to Meral Avc1, Ali Dönmez, S. Tuğrul Körüklü and Begüm Acar for their support and for providing herbarium materials from the GAZI, ISTO, HUB and ANK herbaria.

\section{References}

Abdollahzadeh A, Kazempour O \& Maassoumi AA (2011) Molecular phylogeny of the Genus Salix
(Salicaceae) with an emphasize to its species in Iran. Iran Journal Botany 17: 244-253.

Acar P \& Usta Baykal N (2020) Climate change effects on the distribution of Turkish Salix species: II. International Agriculture Congress (UTAK 2019), Ankara, Turkey. Bahçe 49: 159-165.

Acar P, Taşkıran B, Değirmenci FÖ \& Kaya Z (2020) Turkish Salix species: Molecular phylogeny and morphology. Forestist 70: 141-150.

Akyürek TU \& Acar P (2020) Potential of Turkish Salix L. species: Bioactivity and phytochemistry-a review: 3rd International Eurasian Conference on Biological and Chemical Sciences (EurasianBioChem 2020), Ankara, Turkey, pp. 959-965.

Alakkari LMM (2017) Investigation of the antimicrobial activity of some species to Salix. M.Sc Thesis, Kastamonu University, Kastamonu, Turkey.

Alvarez I \& Wendel JF (2003) Ribosomal ITS sequences and plant phylogenetic inference. Molecular Phylogenetics and Evolution 29: 417-434. doi: 10.1016/S1055-7903(03)00208-2.

Argus GW (1997) Infrageneric classification of Salix (Salicaceae) in the New World. Systematic Botany Monographs 52: 1-121. doi: 10.2307/25096638.

Argus GW (2010) Salix: Flora of North America, vol. 7: Magnoliophyta: Salicaceae to Brassicaceae. Oxford University Press, New York, NY, USA, pp. 23-51.

Arıhan O \& Güvenç A (2009) Ankara çevresinde yetișen söğüt (Salix L.) türleri. Ot Sistematik Botanik Dergisi: 15-52.

Azuma T, Kajita T, Yokoyama J \& Ohashi H (2000) Phylogenetic relationships of Salix (Salicaceae) based on $r b c L$ sequence data. American Journal of Botany 87: 67-75. doi:10.2307/2656686.

Babac MT (2004) Possibility of an information system on plants of South-West Asia with particular reference to the Turkish Plants Data Service (TÜBIVES). Turkish Journal of Botany 28: 119-127.

Bakker FT, Culham A, Gomez-Martinez R, Carvalho J, Compton J, Dawtrey R \& Gibby M (2000) Patterns of nucleotide substitution in angiosperm cpDNA trnL (UAA)-trnF (GAA) regions. Molecular Biology and Evolution 17: 1146-1155. doi:10.1093/oxfordjournals.molbev.a026397.

Barkalov VY \& Kozyrenko MM (2014) Phylogenetic relationships of Salix L. subg. species (Salicaceae) according to sequencing data of intergenic spacers of the chloroplast genome and ITS rDNA. Russian Journal of Genetic 50: 828-837. doi:10.1134/ S1022795414070035.

Bilgin R (2011) Back to the suture: the distribution of intraspecific genetic diversity in and around Anatolia. International Journal of Molecular Sciences 12: 4080-4103. doi:10.3390/ijms12064080.

Brunsfeld SJ, Soltis DE \& Soltis PS (1991) Patterns of genetic variation in Salix section Longifoliae (Sali- 
caceae). American Journal of Botany 78: 855-869. doi:10.1002/j.1537-2197.1991.tb14488.x.

Chen J, Sun H, Wen J \& Yang Y (2010) Molecular phylogeny of Salix L. (Salicaceae) inferred from three chloroplast datasets and its systematic implications. Taxon 59: 29-37. doi:10.1002/tax.591004.

Collinson ME (1992) The early fossil history of Salicaceae: a brief review. Proceedings of the Royal Society of Edinburgh. Section B. Biological Sciences 98, Edinburgh, pp. 155-167. doi:10.1017/ S0269727000007521.

Davis PHR (1965) Flora of Turkey and the East Aegean Islands, Edinburgh University Press, pp. 694-716.

Degirmenci FO, Acar P \& Kaya Z (2019) Consequences of habitat fragmentation on genetic diversity and structure of Salix alba L. populations in two major river systems of Turkey. Tree Genetics \& Genomes 15: 59. doi:10.1007/s11295-0191365-2.

Dorn RD (1976) A synopsis of American Salix. Canadian Journal of Botany 54: 2769-2789. doi:10.1139/b76-297.

Doyle JJ \& Doyle JL (1987) A rapid DNA isolation procedure for small quantities of fresh leaf tissue. Phytochemistry 19: 11-15.

Drummond AJ \& Rambaut A (2003) BEAST version 1.3 (computer program).

Drummond AJ \& Rambaut A (2007) BEAST: Bayesian evolutionary analysis by sampling trees. BMC Evolutionary Biology 7: e214. doi:10.1186/14712148-7-214.

Ekim T \& Güner A (1986) The Anatolian Diagonal: fact or fiction? Proceedings of the Royal Society Edinburgh 89B: 69-77. doi:10.1017/ S0269727000008915.

Evlard A, Druart P \& Collinet G (2014) Using Salix spp. in phytostabilization of metal pollution in soils: an example of phytoremediation appropriate to the brownfields of Wallonia. Poster: 19th National Symposium on Applied Biological Sciences. Gembloux. Belgium.

Erinç S (1978) Changes in the physical environment in Turkey since the end of the last glacial: The environmental history of the Near and Middle East since the last ice age (ed. by WC Brice) Academic Press, London, pp. 87-110.

Fang ZF (1987) On the distribution and origin of Salix in the world. Journal of Systematics and Evolution 25: 307-313.

FAO (2020) Synthesis of country progress reports (Draft). The International Commission on Poplars and Other Fast-Growing Trees Sustaining People and the Environment (IPC), Rome, Italy.

Futuyma, DJ (2011) Evolution. 2nd ed. Sinauer Associates, Sunderland.
Güner A (2000) Salix, L.: Flora of Turkey and the East Aegean Islands, VOL. 11 (ed. by A Güner, N Özhatay, T Ekim \& KHC Başer) Edinburgh University Press, Edinburgh.

Güner A, Aslan S, Ekim T, Vural M \& Babaç MT (2012) Türkiye Bitkileri Listesi (Damarlı Bitkiler). Nezahat Gökyiğit Botanik Bahçesi ve Flora Araştırmaları Derneği yayını. İstanbul, pp. 836839.

Hamza-Babiker N, Heinze B, Glossl J \& Arnold C (2009) Chloroplast DNA identification of eight closely related European Salix species. Austrian Journal of Forest Science 126: 175-193.

Hardig TM, Anttila CK \& Brunsfeld SJ (2010) A phylogenetic analysis of Salix (Salicaceae) based on matK and ribosomal DNA sequence data. Journal of Botany 1-12. doi:10.1155/2010/197696.

Hilu KW, Borsch T, Muller K, Soltis DE, Soltis PS, Savolainen V, Chase MW, Powell MP, Alice LA, Evans R, Sauquet H, Nainhuis C, Slotta TAB, Rohwer JG, Campbell CS \& Chatrou LW (2003) Angiosperm phylogeny based on matK sequence information. American Journal of Botany 90: 1758-1776. doi:10.3732/ajb.90.12.1758.

Hörandl E, Florineth F \& Hadacek F (2012) Weiden in Österreich und angrenzenden Gebieten (willows in Austria and adjacent regions). University of Agriculture, Vienna.

Hsiao C, Chatterton NJ, Asay KH \& Jensen KB (1995) Phylogenetic relationships of the monogenomic species of the wheat tribe, Triticeae (Poaceae), inferred from nuclear rDNA (internal transcribed spacer) sequences. Genome 38: 211-223. doi:10.1139/g95-026.

Karrenberg S, Edwards PJ \& Kollmann J (2002) The life history of Salicaceae living in the active zone of floodplains. Freshwater Biology 47: 733-748. doi:10.1046/j.1365-2427.2002.00894.x.

Kasaplıgil B (1977) Ankara, KızılcahamamYakınındaki Güvem Köyü Civarında Bulunan Son Tersiyer Kozalaklı-Yeşil Yapraklı Orman, Journal MTA 88: 94-100.

Kaya Z \& Raynal DJ (2001) Biodiversity and conservation of Turkish forest. Biological Conservation 97: 131-141. doi:10.1016/S0006-3207(00)00069-0.

Kuzovkina YA, Weih M, Romero M A, Belyaeva I, Charles J, Hurst S, Karp A, Labrecque M, McIvor I, Singh N B, Smart L, Teodorescu T, Trybush S \& Volk T (2008) Salix: botany and global horticulture. Horticultural Reviews 34: 447-489.

Lauren-Moreau A, Pitre EF, Argus GW, Labrecque M \& Brouillet L (2015) Phylogenetic relationships of American Willows (Salix L., Salicaceae). PLoS ONE 10: e0138963. doi:10.1371/journal. pone. 0138963.

Ledig FT (1998) Genetic diversity in tree species, with special reference to conservation in Turkey 
and the eastern Mediterranean: The proceedings of International Symposium on In situ Conservation of Plant Genetic Diversity 231-247, CRIFC, Turkey.

Leskinen E \& Alström-Rapaport C (1999) Molecular phylogeny of Salicaceae and closely related Flacourtiaceae: evidence from $5.8 \mathrm{~S}$, ITS 1 and ITS 2 of the rDNA. Plant Systematics and Evolution 215: 209-227. doi:10.1007/BF00984656.

Li JH, Bogle AL \& Klein AS (1997) Interspecific relationships and genetic divergence of the disjunct genus Liquidambar (Hamamelidaceae). Rhodora 99: 229-240.

Liu X, Wang Z, Dongsheng W \& Zhang J (2016) Phylongeny of Populus-Salix (Salicaceae) and their relative genera using molecular data set. Biochemical Systematics and Ecology 68: 210-215. doi:10.1016/j.bse.2016.07.016.

Librado P \& Rozas J (2009) DnaSP v5: A software for comprehensive analysis of DNA polymorphism data. Bioinformatics 25: 1451-1452. doi:10.1093/ bioinformatics/btp187.

Mahdi JG, Mahdi AJ \& Bowen ID (2006) The historical analysis of aspirin discovery, its relation to the willow tree and antiproliferative and anticancer potential. Cell Proliferation 39: 147-155. doi:10.1111/j.1365-2184.2006.00377.x.

Mutun S (2016) Review of oak gall wasps phylogeographic patterns in Turkey suggests a main role of the Anatolian diagonal. Türk Orman Dergisi 17: 1-6. doi:10.18182/tjf.65861.

Nylander JAA (2004) MrModeltest v2. Program distributed by the author. Evolutionary Biology Centre, Uppsala University.

Ohashi H (2001) Salicaceae of Japan. Science Reports of the Tohoku University. Series 4, Biology 40: 269-396.

Özdilek A, Çengel B, Kandemir G, Tayanç Y, Velioğlu E \& Kaya Z (2012) Molecular phylogeny of relict endemic Liquidambar orientalis mill based on sequence diversity of the chloroplast-encoded matK gene. Plant Sytematics and Evolution 298: 337-349. doi:10.1007/s00606-011-0548-6.

Patterson J, Chamberlain B \& Thayer D (2004-2006) Finch TV Version 1.4.0.

Percy DM, Argus GW, Cronk QC, Fazekas AJ Kesanakurti PR, Burgess KS, Husband BC, Newmaster SG, Barrett SCH \& Graham SW (2014) Understanding the spectacular failure of DNA barcoding in willows (Salix): Does this results from a trans specific selective sweep? Molecular Ecology 23: 4737-4756. doi:10.1111/mec.12837.

Pirie MD, Balca MP, Vargas Z, Botermans M, Bakker FT \& Chatrou LW (2007) Ancient paralogy in the cpDNA trnL-F region in Annonaceae: implications for plant molecular systematics. American
Journal of Botany 94: 1003-1016. doi:10.3732/ ajb.94.6.1003.

Rambaut A, Suchard MA, Xie D \& Drummond AJ (2014) Tracer v1.6. Available from http://beast. bio.ed.ac.uk/Tracer.

Rambaut A (2016) Figtree 1.4.3. Website http:// tree.bio.ed.ac.uk/software/figtree/.

Savolainen V, Fay M, Albach DC, Backlund A, Bank, Cameron KM, Johnson SA, Lledo MD, Pintaud JC, Powell M, Sheahan MC, Soltis DE, Soltis PS, Weston P, Whitten WM, Wudrack KJ \& Chase MW (2000) Phylogeny of the Eudicots: A nearly complete familial analysis based on $r b c L$ gene sequences. Kew Bulletin 55: 257-309. doi:10.2307/4115644.

Skvortsov AK (1999) Willows of Russia and adjacent countries: Taxonomical and Geographical Revision. Nauka Publishers, Moscov.

Stegemann S, Keuthe M, Greiner S \& Bock R (2012) Horizontal transfer of chloroplast genomes between plant species. Proceedings of the National Academy of Sciences of the United States of America 109: 2434-2438. doi:10.1073/ pnas.1114076109.

Taberlet P, Gielly L, Pautou G \& Bouvet J (1991) Universal primers for amplification of three non-coding regions of chloroplast DNA. Plant Molecular Biology 17: 1105-1109.

Tamura K, Stecher G, Peterson D, Filipski A \& Kumar S (2013) MEGA6: Molecular Evolutionary Genetics Analysis version 6.0. Molecular Biology and Evolution 30: 2725-2729. doi:10.1093/molbev/ mst197.

Terzioğlu S, Coşkunçelebi K \& Serdar B (2007) Contribution to the description of an endemic Turkish Salix species. Plant Biosystems 141: 82-85. doi:10.1080/11263500601154055.

Vermerris W (2008) Genetic improvement of bioenergy crops. Springer, New York, pp. 347-362.

Wagner ND, Hörandl E \& Gramlich S (2018) RAD sequencing resolved phylogenetic relationships in European shrub willows (Salix L. subg. Chamaetia and subg. Vetrix) and revealed multiple evolution of dwarf shrub. Ecology and Evolution: 82438255. doi:10.1002/ece3.4360.

Wagner ND, He L \& Hörandl E (2020) Phylogenomic relationships and evolution of polyploid Salix species revealed by RAD sequencing data. Frontiers in Plant Science 11: 1-15. doi:10.3389/ fpls.2020.01077.

Wayne P \& Knowles LL (2006) Inferring phylogeny despite incomplete lineage sorting. Systematic Biology 55: 21-30. doi:10.1080/10635150500354928.

Wolfe JA (1987) An overview of the origins of the modern vegetation and flora of the Northern Rocky Mountain. Annals of the Missouri Botanical Garden 74: 785-803. doi:10.2307/2399450. 
Wu J, Nyman T, Wang D, Argus GW, Yang Y \& Chen JH (2015) Phylogeny of Salix subgenus Salix s.l. (Salicaceae): delimitation biogeography and reticulate evolution. BMC Evolutionary Biology 15: 31. doi:10.1186/s12862-015-0311-7.

Zhao Y, Liu X, Guo R, Hu K, Cao Y \& Dai F (2019) Comparative genomics and transcriptomics analysis reveals evolution patterns of selection in the Salix phylogeny. BMC Genomics 20: e253. doi:10.1186/s12864-019-5627-z.
Zieliński J \& Güner A (2000) Zelkova Spach: Flora of Turkey and the East Aegean Islands (ed. by AGüner, N Özhatay, T Ekim \& KHC Başer KHC) Edinburgh University Press, Edinburgh.

Zieliński J \& Tomaszewski D (2007) Salix anatolica (Salicaceae), a new species from Turkey. Annales Botanici Fennici 45: 386-388. doi:10.5735/085.045.0506. 